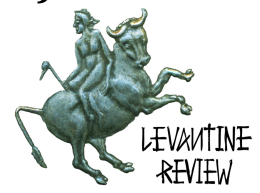

\title{
HEBREW AND ARAMAIC ELELMENTS IN THE ISRAELI VERNACULAR CHRISTIAN-ARABIC AND IN THE WRITTEN CHRISTIAN ARABIC OF Palestine, SYRIA, AND LEBANON
}

\author{
Ibrahim Bassal*
}

\begin{abstract}
This essay examines the Hebrew and Aramaic residues in the Arabic vernacular spoken by Israeli Christians and the written Arabic of Christians in the Holy Land, Syria, and Lebanon. The corpus of the spoken Christian-Arabic under consideration here is based on cassette recordings of elderlies who live in Christian villages in northern Israelnamely in Fassuta, Me'ilya, Tarshiha, Bqe'a, Jiish, Kufir Yasif, Ekreth, Bir'im Ibilleen and Shfa'amir. The corpus of the written Christian-Arabic being reviewed is based mainly on folk tales, poems, proverbs, dictionaries, Bible translations, books of interpretation, and liturgical sources.
\end{abstract}

It is reasonable to maintain that substrata from languages spoken in the Levant prior to the seventh century Muslim conquest have been preserved in Arabic, given that Arabic itself only gradually replaced those antecedent languages. This is especially the case with Aramaic, the spoken language of the Levant, which was gradually pressed down since the beginning of the Arab conquest in the early seventh century and until the tenth century. ${ }^{1}$ Together with that, Aramaic substrata can be witnessed in the diglossia and the linguistic habits of the inhabitants of Lebanon, Syria, and Palestine in the era preceding the modern domination of Arabic. Nevertheless, these Aramaic substrata have remained in today's Levantine Arabic, both in its spoken and written forms - that is to say, in Modern Standard Arabic and the various vernacular languages.

Yihezkiel Kutscher who has written on Aramaic elements in the Hebrew Encyclopedia maintained that Aramaic elements have also remained dominant in the Arabic dialects of localities where Aramaic had once been the native tongue. ${ }^{2}$ However, Avishur, in his paper on the Iraqi Judaeo-Arabic, hints that the research

1 Abba Ben-David, Biblical Hebrew and Mishnaic Hebrew,( Dvir, Tel-Aviv 1967), vol. I, 153-65; Joseph Naveh \& Jonas C. Greenfield, "Hebrew and Aramaic in the Persian Period" in The Cambridge History of Judaism, W.D. Davies, L. Finkelstein, (ed.), Cambridge 1999, vol. I, pp. 115-129.

2 Kutscher 1971, Hebrew Encyclopedia, vol. 5, p.968. 


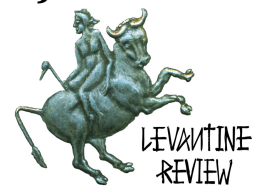

done on this topic remains limited and imperfect, and could benefit from more attention. ${ }^{3}$ Indeed, the literature that deals with this topic is unanimous with regards to "word-lists" and the like, compiled mostly by priests, and which clearly point to Aramaic and Hebrew substrates. But this work should still be examined through a scientific lens.

Not much has been written on the Hebrew and Aramaic influence on Arabic in terms of pronunciation, form, and syntax, except in the work of Lebanese philologist and clergyman Michel Feghali-namely in his books on the Aramaic remnants in the syntax, pronunciation, morphology, and vocabulary of the Arabic spoken in Lebanon. ${ }^{4}$

In fact, there remains a dearth in terms of systematic comprehensive research dealing with this topic in a methodical, inclusive, and summarizing manner, integrating the Hebrew and Aramaic elements permeating both literary and spoken Levantine Arabic. Therefore, using as a model recent research on the influence of Aramaic on "Judeo-Arabic," this study 5 seeks to examine and complement the topic of Aramaic influence on "Christian Arabic" thoroughly and comprehensively, touching upon issues of pronunciation, morphology, syntax, and vocabulary.

For the purpose of this study, I have gathered and condensed the Hebrew and Aramaic elements that have penetrated the spoken and written Arabic used by the Christians of Lebanon, Syria, and Palestine. One cannot overstate the importance of gathering and preserving this kind of material-if only for the purpose of documenting and safeguarding a tradition that may otherwise be on the way to extinction, alongside the atrophied and ever dwindling numbers of Near Eastern Christians. The speedy societal changes in the Levantine region have led to farreaching transformations in the lifestyle (and especially in language and linguistic habits) that were once a way of life, but that are today slowly disappearing or transforming. The corpus of an Aramaic lexicon, which was once part of daily usage

3 Yitzhak Avishur, "The Ancient Aramaic Elements in the Iraqi Judaeo-Arabic", Masorot 9-10-11, (1997 Jerusalem), pp. 277-94.

4 Mitchel Feghali, Étude sur Les Emprunts Syriaques dans Les Parlers Arabes du Liban, Paris 1918; Mitchel Feghali, Le Parler de Kfar 'Abida (liban-syrie) -Essai Linguistique sur La Phonétique et La Morphologie d'un Parler Moderne, Paris(1919); Mitchel Feghali, Syntaxe des Parllers Arabes Actuels du Liban, Paris 1928.

5 Ibrahim Bassal, Hebrew and Aramaic elements in the Vernacular Christian Arabic in Israel and in the written Christian Arabic in the Holy Land, Syria and Lebanon, (Dissertation), Haifa University, 2004. [in Hebrew] 


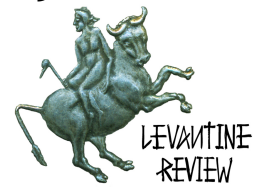

throughout the Levant, is falling out of use today, is being slowly forgotten, and is tending toward fading away, especially among the younger generations.

Furthermore, as most informants advance further in age, it is a duty incumbent upon the linguist to preserve and safeguard a vanishing linguistic tradition, before this march toward extinction becomes irreversible.

In this study I also examine the way of the infusion of Hebrew and Aramaic elements into Arabic, and I point to the changes that have occurred within them as a result. To wit, I cross-check the Hebrew and Aramaic elements that exist in the spoken Arabic, and between them and those that exist in the written language. In my opinion, this cross-checking is likely to show the circulation of the Hebrew and Aramaic elements and their fusion within both the spoken and the written Arabic, and even the transmission of those two registers. The cross-checking also points to the exclusiveness and peculiarity of the layers of spoken Arabic in the Holy Land (that is to say the Palestinian varieties of the Christian dialects) in comparison with other Arabic-defined dialects. This also clarifies the linkage between these layers and the languages that were once spoken in Palestine-languages such as Hebrew and Aramaic. Researching these elements linguistically contributes to determining the location of the Arabic-defined vernaculars spoken by Christians within the map of the dialectology of the spoken Arabic in Israel.

Furthermore, researching the Hebrew and the Aramaic components in these layers contributes to the definition of the Arabic linguistic atlas in general, and the unique linguistic atlas of the spoken dialects of Christians. Additionally, this contributes to eventually the completion of a Christian Palestinian Arabic Lexicon. Comparatively, this research is likely to contribute to clarifying some obscurities in the Bible. Blau states that the importance of the spoken Arabic dialect in the Holy Land, which in his view preserves elements and words that might enlighten and contribute to the explanation of difficult words and forms of the Biblical vocabulary, which it seems settled in the mouths of the Arabic-speaking residents in Israel. ${ }^{6}$

The Arab-defined Christians in Israel and the Arabophone Christians are part of Christian communities of the Near East and the Levant. They live in an Islamic environment in Egypt, Iraq, Syria, and Lebanon. They are also surrounded by a Jewish population that constitutes the majority of the population in Israel.

However, in spite of their Islamic environment and their use of the Arabic language, they keep their religious identity as Christians, and in parts of the region, in areas such as Lebanon, Syria, Iraq, and even Egypt, they observe their prayers and

6 Yehoshua Blau, "Etymologische Untersuchungen auf Grund des palästinischen Arabisch", Vetus Testamentum 5 (1955), pp. 337-344. 


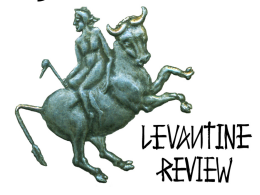

religious rites and ceremonies in their original languages-that is to say in AramaicSyriac in Iraq, Lebanon, and Syria, and in Coptic in Egypt. The Arab-defined and Arabophone Christians who live in Israel today count some 113, 700 people according to the data of the Central Department of Statistics (Annual Statistic of Israel, 2003, No. 54). Those Christians are mainly concentrated in the North of the country. They are united and are different from the rest of the Arab-defined Muslim population in their rites and linguistic habits; their vocabulary is exclusive (reflecting their Church languages,) and their names are exclusive often reflecting Western orientation, and their saints' names as rendered in Western languages.

The spoken Arabic of Israel is varied in its dialects. It could be distinguished according to region, religious affiliation, or urban and rural communities. In the south of the country, the Bedouin dialect is the most widely used speech form. ${ }^{7}$ In the center, and in the triangle region, there exists a distinct exclusive dialect. ${ }^{8}$ And in the north of the country, the Galilean dialects are the most common linguistic cluster. A number of studies have been written about the Arabic dialects in Israel and Palestine. ${ }^{9}$ The common denominator of these studies that they he not not

${ }^{7}$ On the Bedouin Dialect of the Negev see, Haim Blanc, The Arabic Dialect of the Negev Bedouins, The Israel Academy of Sciences and Humanities, Jerusalem 1970; Mosa Shawarbah, On the Bedouin Dialect of the Tiyaha in the Negev: Phonology, Morphology, and Selected Syntactical Issues (Dissertation) 2007 [Hebrew]; Rony Henkin, Negev Arabic: Dialectal, Sociolinguistic, and Stylistic Variation. Wiesbaden: Harrassowitz 2010.

8 Otto Jastrow, "The Arabic Dialects of the Muthallath (central Israel)" JSAI 29 (2004), pp. 166-175.

9 There are several works about Palestinian Arabic dialects: Gotthelf Bergstrasser, Sprachatlas von Syrien und Palastina, Leipzig: J.C. Hinrichs 1915; Haim Blanc, Studies in North Palestinian Arabic. Linguistic Inquiries among the Druzes of Western Galilee and Mt. Carmel, Jerusalem (1953); Moshe Piamenta, The Use of Tenses, Aspects and Moods in the Arabic Dialect of Jerusalem. Jerusalem, Bureau of Adviser on Arab Affairs, Prime Minister Office 1964; Heiniki Palva, Lower Galilean Arabic: An Analysis of its Anaptyctic and Prothetic Vowels with Sample Texts, Helsinki 1965; Judith Rosenhouse, The Bedouin Arabic Dialects, General Problems and a Close Analysis of North Israel Bedouin Dialects, Wiesbaden 1984; Arie Levin, A Grammar of the Arabic Dialect of Jerusalem, Magness Press, Hebrew University, Jerusalem 1995;Ahron Geva-Kleinberger, Die arabischen Stadtdialekte von Haifa in der ersten Halfte des 20, Wiesbaden: Harrassowitz 2004; Ahron Geva-Kleinberger, Autochthonous texts in the Arabic dialect of the Jews of Tiberias, Wiesbaden: Harrassowitz 2009; Abed Khariush, Palestinian Dialects- A Phonological Study, Amman 2004 a book about the phonological description of the Palestinian dialects, 


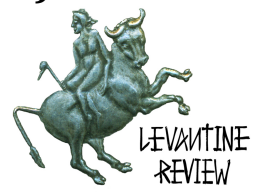

dealt with the Aramaic influence on Arabic. In fact, there is no methodical and comprehensive research on the topic that integrates the post-classical Hebrew and Aramaic elements existing in both literary and spoken languages of the region, especially in Palestine.

As mentioned earlier, this paper is based on researching the Aramaic and Hebrew elements in the spoken Arabic of Israeli Christians, and the written Arabic of the Christian communities in Israel, Syria, and Lebanon. The paper is structured in a way so as to examine two main corpora: the first, the corpus of the Arabic spoken by the Christians of Israel. In order to research the spoken corpus of this community, I carried out interviews and conversations with informants, and I tape-recorded twenty informants among elderly Christians from northern villages in Israel. Those elderly subjects did not know modern Hebrew, and their education, if any, was scant and limited.

The second corpus examined in this paper is that of the written tradition, including the Christian rites, Bible translations, New Testament, Christian liturgical literature, and folk tales in Christian Arabic. In my opinion, examining the two corpora allows for a complete and comprehensive description of the Hebrew and Aramaic linguistic elements. It also enables examining the penetration and infusion of these elements into the Christian Arabic, both in its spoken and written forms. Additionally, examining both written and spoken corpora enables the classification of the elements that penetrated only the spoken language, or only written texts. Elements that exist in the spoken language indicate that they remain in the spoken form and have not passed into the literary language. Elements in both spoken and written language may show that the borrowing has taken place from the spoken and passed into the written language as well. This points to the depth of the infusion and penetration of these elements in the absorbing language. Words that exist only in the written language indicated that borrowing is only in the written language. I think that putting the two corpora and crossing the linguistic categories together is likely to give a full picture of the range of the Hebrew and Aramaic elements in

through surveying the researches that had dealt with the Palestinian dialect, its distribution and linkage to old Arab dialects [in Arabic]. 


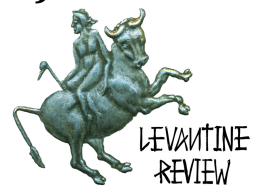

them, and even point out the domains of their use in both written and spoken Christian Arabic.

The so-called "Christian Arabic" is the spoken and written language of Christians among Christians. This fact is of great importance in the description of the characteristics of this language. The Christian community in the Levant has written an extensive Arabic literature in both the Arabic and Syriac (Karshuni) scripts. ${ }^{10}$ In the classical (pre-Islamic) era, there were known Christian poets who composed classical Arabic verse where one can find a sizeable number of religious words linked to Christianity and Judaism. ${ }^{11}$ Moreover, Aramaic and Hebrew words exist in the liturgical religious literature, linked to church matters.

Arab philologists have determined a method to identify the foreign elements in the Arabic language. They identified foreign words by means of phonological, morphological, and semantic criteria. In general, they preceded expressions and combinations before foreign words that indicate their foreignness or suspicion of

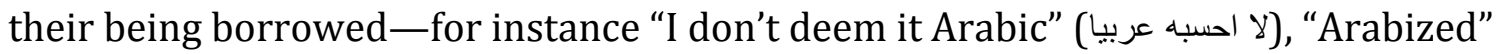

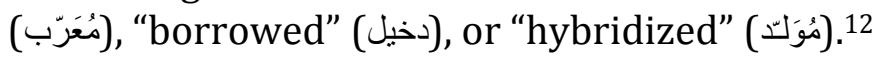

In his collection of Arabicized words, al- Ğawālīqīîn (d.1144) mentioned a number of Hebrew words which were mostly personal names. In the modern era, al-Yasū' ${ }^{14}$ wrote a comprehensive collection of foreign words in Arabic, in which there is a chapter that counts about forty Hebrew words, mostly names, with the remainder being words of religious provenance. More recent works deal with the borrowed

10 Adam Carter MCcollum, "Garshuni as it is: Some Observations from Reading East and West Syriac Manuscripts", Hugoye: Journal of Syriac Studies, Vol. 17.2 (2014), 215-235.

11 See: L. Cheikho, Le Christianisme et La Littérature Chrétienne en Arabie Avant L'Islam, 2 édition, Dar-El-Machreq, Beyrouth 1989.

12 For more details, see I. BASSAL, (2013). "Syriac-Aramaic words in an early Christian Arabic copy of the Pentateuch (Ms Sin. Ar. 2), Collectanea Christiana Orientalia (CCO) 10 (2013), p. 21 note 9.

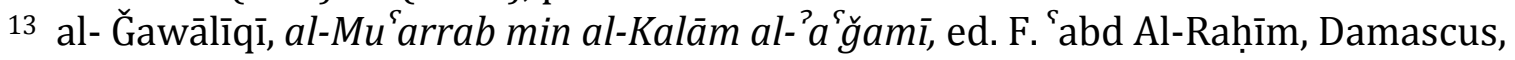
1990.

14 Rufa el Naxleh al-Yasū ${ }^{\varsigma} y$, GHarā ib al-Lugha al- ${ }^{\varsigma}$ Arabiyya, al-Mața ${ }^{\varsigma}$ a alKāthulikiyya, Beirut 1959. 


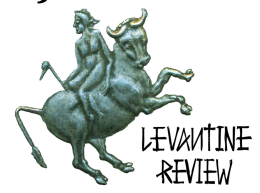

Aramaic elements in Arabic-for instance Fraenkel (1886), ${ }^{15}$ Hobaika $(1902,1904$ and 1939), ${ }^{16}$ Feghali (1919), ${ }^{17}$ and Agnathius (1969). ${ }^{18}$

Judaeo-Arabic has been greatly researched in the context of its Aramaic and Hebrew elements; see for instance Goitein (1931), Leslau (1945), and Bar-Asher (1978 and 1999) who outlined a basis and a method for the research of the Hebrew element in the Judaeo-Arabic. Schwarzwald (1984) related to measures for the infusion of Hebrew and Aramaic words in the Jewish Spanish language. Also Maman (1989) wrote an article about identifying the Hebrew element in Moroccan Jewish Arabic. Bahat (1990 and 2002) related to the Hebrew element in the written Arabic of Jews of Morocco. Henshki (2007) wrote about the Hebrew element in the spoken Arabic of the Jews of Tunisia. ${ }^{19}$ Avishur (1997) presented a new method for researching the Jewish-Aramaic element in the Judaeo-Arabic of the Levant by way of examining the Hebrew and Aramaic elements in the written and oral transition of language. ${ }^{20}$

15 Sigmund Fraenkel, Die Aramäischen Fremdwörter im Arabischen, Leiden 1886.

16 J. Hobeika, Etymologie arabo-syriaque. Mots et Locutions Syriaques dans l'Idiom Vulgaire du Liban et de la Syrie = al- dawātir. baḥt fī baqāyā al-luġa al-suryāniyya fì al-luǵa al- '̄àmmiyya fi Lubnān wa-sūriyya 2 vols. (Jounieh 1902-3/ByrouthBasconta (Liban) of which rare work large portions are reprinted in Al-Machriq 37 (1939), pp. 289-412.

17 Mitchel Feghali, Le Parler de Kfar 'Abida (liban-syrie) -Essai Linguistique sur La Phonétique et La Morphologie d'un Parler Moderne, Paris 1919.

18 Aghnatius Ya qūb III, al-Barāhīn al-Hissiyya 'ala Taqāruḍ al-suryāniyya wa'arabiyya, Damascus 1969.

19 Salomon Dov Goitein, "The Hebrew elements in the vernacular of the Yemenite Jews". LEŠONENU 3 (1931), pp. 356-380. (In Hebrew.); W. Leslau, "Hebrew Elements in the Judaeo-Arabic Dialect of Fez" J.Q.R. 36 (1945), pp. 61- 78; M. BarAsher, "Eléments hébreux dans le Judéo-arabe marocain, LEŠONENU 42 (1978) pp. 163-189 [in Hebrew]; Y. Bahat, La Composante Hébraïque de l'arabe écri des Juifs du Maroc, Institut Bialik, Jerusalem 2002; Aharon Maman, “On identifying Hebrew Elements in Judeo-Maghrebian", Masorot 3-4 (1989) pp.171-201 [in Hebrew]; 0. Schwarzwald, "Determining Criteria for the Fusion of the HebrewAramaic Component in Judeo-Spanish. Milet 2: 1984 (Everyman's University Annual), 357-367. [in Hebrew]; Yehudit Henshke, Hebrew Elements in Daily Speech: A Grammatical Study and. Lexicon of the Hebrew Component of Tunisian Judeo-Arabic, Jerusalem, 2007. [in Hebrew]

20 Yitzhak Avishur, "The Study of Hebrew Elements from Oral Traditions and Written Sources of Oriental Judaeo-Arabic", Masorot 9-10-11, (1997), pp. 277294. 


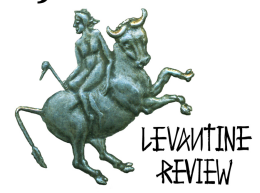

It is based on the preceding that this paper examines the Hebrew and Aramaic elements (words and forms) using solid linguistic criteria and measures-namely spelling, pronunciation, morphology and syntax.

The borrowed elements that are examined in this paper, in both the spoken and written languages, are mainly from Post-Biblical Hebrew, and from Aramaic, Syriac, and their various dialects. As is well known, Arabic spread (and became widespread) throughout the urban areas of the Levant beginning in the seventh century. It became a dominant-albeit not an exclusive-language beginning in the ninth and tenth centuries. ${ }^{21}$ Within that linguistic space, Aramaic was still a living spoken language, and it was therefore normal for Arabic to have had direct contact with that vibrant linguistic layer, which had left a visible linguistic and cultural mark, to the point of influencing Classical Arabic. ${ }^{22}$

In Palestine, Syria, and Lebanon, languages that were supposed to have affected the Arabic dialects were remnants of late Aramaic-including Galilean Aramaic, Syriac, and Palestinian Syriac (or Christian Aramaic) in Palestine, and Samaritan Aramaic and Syriac which was spoken in Syria and Iraq. However, I believe that it would have been difficult to separate the elements and divide them into Aramaic layers and their dialects. Since there is kinship among the Aramaic dialects, and since Aramaic was a dominant language for a very long time in the Syriac-speaking region (Palestine included,) the substrates that were left in the spoken Arabic of the Levant are overwhelming. What is more, the influence from languages other than Aramaic-for instance Hebrew, Akkadian ${ }^{23}$, and Greek-which passed to both the written and spoken Arabic via Aramaic, remains very strong. See below for instance:

\begin{tabular}{|c|c|c|c|}
\hline "Arabic" & Transliteration & Syriac & Meaning \\
\hline صباؤوت & Șaba'ūt & 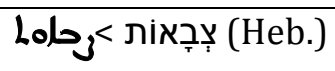 & Armies \\
\hline هيكل & Haykal & とる < ekallu (Akk) & Temple \\
\hline
\end{tabular}

21 Spencer Trimingham, Christianity among the Arabs in Pre-Islamic Times, London 1979, pp. 2-3; Kees Versteegh, Pidginization and Creolization: The Case of Arabic, Amesterdam/Philadelphia: John Benjamins Publishing Company 1984, pp. 73-74; Kees Versteegh, The Arabic Language, Edinburgh University Press 2014, pp. 126132.

22 See Sigmund Fraenkel, Die Aramäischen Fremdwörter im Arabischen, Leiden 1886.

23 Stephen Kaufman, The Akkadian Influences on Aramaic, Chicago 1974. 


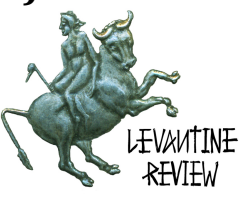

\begin{tabular}{|c|c|c|c|}
\hline زنبيل & Zanbīl & 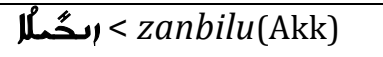 & Basket \\
\hline >>يلول & Eylūl & 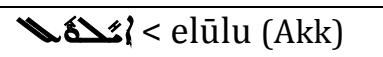 & September \\
\hline > & Aab & Dk $a b u($ Akk) & August \\
\hline > > خكارة & Shkārah & |مُ | > iškaru (Akk) & Acre \\
\hline اسكولين & Askūlīn & 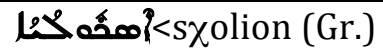 & Scholars \\
\hline
\end{tabular}

\section{DIVISION OF THE POST-BIBLICAL HEBREW AND ARAMAIC ELEMENTS}

The Hebrew and Aramaic elements that penetrated the spoken and written Arabic were mostly nouns, adjectives and often verbs. These elements are divided into a number of categories:

1- There are Aramaic elements that penetrated the literary Arabic and that can be found in parts of the dialects.

2- There are Hebrew and Aramaic elements, exclusive to a certain dialect, and which can be found in the various communities that speak that very dialect, such as the Christians in Israel-Palestine, Syria, and Lebanon.

3- There are Hebrew and Aramaic elements, exclusive to the written and spoken Christian Arabic.

4- There are Hebrew and Aramaic elements, exclusive only to the written Christian Arabic.

In the context of the Christian Arabic evaluated in this study, elements may be divided into such divisions as follows:

1- There are Aramaic elements that penetrated the literary Arabic and that can be found in parts of the dialects.

\begin{tabular}{|c|c|c|c|}
\hline Aramaic & Meaning & Aramaic & Meaning \\
\hline إl > أتون > > & furnace & محهرلا > شبَوط & $\begin{array}{l}\text { Fish covered } \\
\text { with scales }\end{array}$ \\
\hline حلهر > كانون & brazier & موها > سفط & basket \\
\hline קִרְמִיד > قِرْمِيد & Brick & סטלא > سطل & Bucket \\
\hline سـ:| >نير & Yoke & 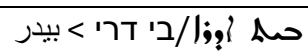 & Threshing \\
\hline
\end{tabular}




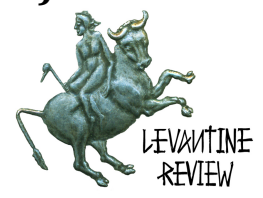

\begin{tabular}{|c|c|c|c|}
\hline & & & floor \\
\hline ملبمار > قنديل & lamp & حمוا > كوز & $\begin{array}{l}\text { Bottle for } \\
\text { water }\end{array}$ \\
\hline
\end{tabular}

Month Names: ${ }^{24}$

\begin{tabular}{|c|c|c|c|}
\hline $\begin{array}{l}\text { Hebrew and } \\
\text { Aramaic }\end{array}$ & Meaning & $\begin{array}{l}\text { Hebrew and } \\
\text { Aramaic }\end{array}$ & Meaning \\
\hline ? & September & لسمع > نيسان & April \\
\hline لم:مج > تشرين & Oct. and Nov. & إم: > ايّار & May \\
\hline حسهر > كانون & Dec., and Jan. & مله: > > حزير ان & June \\
\hline محله > شباط & February & Lمار > تموز & July \\
\hline إ@ > > اذار & March & إص > آب & August \\
\hline
\end{tabular}

2- There are Hebrew and Aramaic elements, exclusive to a certain dialect, and which can be found in the various communities that speak that very dialect, such as the Christians in Israel-Palestine, Syria, and Lebanon.

The span of this elements belongs to various life domains:

A. Nouns Pertaining to Land, Agricultural Seasons, and Types of Sowing:

\begin{tabular}{|c|c|c|c|}
\hline $\begin{array}{l}\text { Hebrew and } \\
\text { Aramaic }\end{array}$ & Meaning & $\begin{array}{l}\text { Hebrew and } \\
\text { Aramaic }\end{array}$ & Meaning \\
\hline מַעַנְָה > معناية & Furrow & לִגְנְה > لجنة & Row \\
\hline חִגְוֹרָה >>حاكورة & $\begin{array}{l}\text { Ground near } \\
\text { House }\end{array}$ & وحما > دلبيل & Thin \\
\hline لעבי > عبي & Thick & ששוּרָה / مهز| > شورة & Line \\
\hline ممصوا > شقيف & Cliff & נִיר > نير & Ploughing over \\
\hline
\end{tabular}

24 Most of the month names loaned from Akkadian. 


\begin{tabular}{|c|c|c|c|}
\hline צר > صرار & pebbles & /ל?קיש > لقشَّي & Late Rains \\
\hline
\end{tabular}

B. Nouns Pertaining to Weather Conditions:

\begin{tabular}{|c|c|c|c|}
\hline $\begin{array}{l}\text { Hebrew and } \\
\text { Aramaic }\end{array}$ & Meaning & $\begin{array}{l}\text { Hebrew and } \\
\text { Aramaic }\end{array}$ & Meaning \\
\hline معحا > شوب & Harsh Heat & ححمزا > عبورة & Passing Cloud \\
\hline
\end{tabular}

C. Agricultural and Work Tools:

\begin{tabular}{|c|c|c|c|}
\hline $\begin{array}{l}\text { Hebrew and } \\
\text { Aramaic }\end{array}$ & Meaning & $\begin{array}{l}\text { Hebrew and } \\
\text { Aramaic }\end{array}$ & Meaning \\
\hline مهحلر > مخل/نخل & Iron Plow Bar & 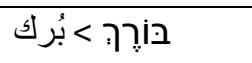 & Plough Knee \\
\hline امهال|>زَقوت & Porcupine/Prick & יִיצוּל > ياصول & Wagon Shaft \\
\hline همهز|> بيور & Ox Goad & مهز محا > قطريب & Yoke Cross \\
\hline مَّمُمْما > مستّاس & Ox Goad & שֵַׁِף > شَلف & Draw \\
\hline محهُما > شلفة & Stick & |محه| > شبيط & Stick \\
\hline مُحةَّل > حالول & Riddle & حلمها > عزقة & Screw/Cog \\
\hline
\end{tabular}

D. Plants:

\begin{tabular}{|c|c|c|c|}
\hline $\begin{array}{l}\text { Hebrew and } \\
\text { Aramaic }\end{array}$ & Meaning & $\begin{array}{l}\text { Hebrew and } \\
\text { Aramaic }\end{array}$ & Meaning \\
\hline حزمعمال > برقوق & apricot & حهمما > عافوق & Weed \\
\hline עוֹלְתִין >علت & Chicory & حصهحا > عكوب & Wild Thorns \\
\hline محمام > قلقاس & Plant & ترحُا > نصبة & Planting \\
\hline |مها >ززوفا & Hyssop & مهزمال > قرمية & Tree Trunk \\
\hline
\end{tabular}


E. House Tools:

\begin{tabular}{|c|c|c|c|}
\hline $\begin{array}{l}\text { Hebrew and } \\
\text { Aramaic }\end{array}$ & Meaning & $\begin{array}{l}\text { Hebrew and } \\
\text { Aramaic }\end{array}$ & Meaning \\
\hline 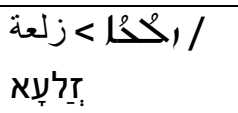 & Bottle & 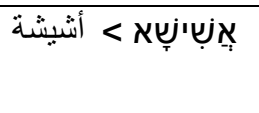 & Jug \\
\hline لحخشه|> طبليّة & Stool & وحمرل > دبّوس & Pin \\
\hline حهل| > بوطة & Vessel & /ọרִידָה > سِريدُة & Straw basket \\
\hline مزها > صر افة & Wooden Box & مممهما > مشطاح & Surface \\
\hline الحملر > زنبيل & Basket & حمزحا > كركية & Container \\
\hline أم: > أفورا & Basket, wine jar & & \\
\hline
\end{tabular}

F. Crops and Fruits:

\begin{tabular}{|c|c|c|c|}
\hline $\begin{array}{l}\text { Hebrew and } \\
\text { Aramaic }\end{array}$ & Meaning & $\begin{array}{l}\text { Hebrew and } \\
\text { Aramaic }\end{array}$ & Meaning \\
\hline גַּרְגרגר > جرجير & $\begin{array}{l}\text { Shrivelled } \\
\text { Olive }\end{array}$ & קֶֶֶֶת > جفت & Olive Waste \\
\hline דוּרָרָה, > דִיפְרָא & First Figs & ه;0مال > فاروح & $\begin{array}{l}\text { Thin Chaff } \\
\text { flying in the } \\
\text { Wind }\end{array}$ \\
\hline נִجְלא > نبلة & Fallen Fig & טרף / > طربون & A Bunch \\
\hline
\end{tabular}

G. Food and Clothing Items:

\begin{tabular}{|c|c|c|c|}
\hline $\begin{array}{l}\text { Hebrew and } \\
\text { Aramaic }\end{array}$ & Meaning & $\begin{array}{l}\text { Hebrew and } \\
\text { Aramaic }\end{array}$ & Meaning \\
\hline מִ & Rennet & همزمُمُلا > برشان & Sacred Bread \\
\hline ه:همرلا > فرفوتة & Crumb & |0ـ:|> زنار & Waist Belt \\
\hline |همال>>زوم & Soup & of >ما > طلموسة & Piece of Bread \\
\hline
\end{tabular}


H. Animals and their Habitat:

\begin{tabular}{|c|c|c|c|}
\hline $\begin{array}{l}\text { Hebrew and } \\
\text { Aramaic }\end{array}$ & Meaning & $\begin{array}{l}\text { Hebrew and } \\
\text { Aramaic }\end{array}$ & Meaning \\
\hline טַפְזָא > طبسون & Rock Rabbit & שְׁעִִיר > صاعور & Male goat \\
\hline مزبمهم > قريدس & Shrimp & مهزبـما > شرنقة & Cocoon \\
\hline שוּנרָא > شنتسار & Partridge & ol 0 > ز غلول & Young Bird \\
\hline אסטבלא > اسطبل & Stable & & \\
\hline
\end{tabular}

I. Residences and Buildings:

\begin{tabular}{|c|c|c|c|}
\hline $\begin{array}{l}\text { Hebrew and } \\
\text { Aramaic }\end{array}$ & Meaning & $\begin{array}{l}\text { Hebrew and } \\
\text { Aramaic }\end{array}$ & Meaning \\
\hline هم;هل > برطاش & Door Threshold & שِשِער > شعريّة & Gate \\
\hline محسا > كلتين & Hard Stone & مهفُ:ْ > سفار ات & Wood Logs \\
\hline ح:مه| > عرقة & beam & קمحه| > جملون & Wooden Frame \\
\hline مهح:| > سكرّة & Door Lock & هص:| > فاكورة & $\begin{array}{l}\text { Confined } \\
\text { Window }\end{array}$ \\
\hline
\end{tabular}

J. Body Parts and Illnesses:

\begin{tabular}{|c|c|c|c|}
\hline $\begin{array}{l}\text { Hebrew and } \\
\text { Aramaic }\end{array}$ & Meaning & $\begin{array}{l}\text { Hebrew and } \\
\text { Aramaic }\end{array}$ & Meaning \\
\hline حا| > بز & Breast & لهمار > طيز & Buttocks \\
\hline ص:حا > كر عوني & Leg & همومـا > فسفوسة & Body Rash \\
\hline
\end{tabular}

3. There are Hebrew and Aramaic elements that penetrated both the spoken and the written Christian Arabic. For example:

\begin{tabular}{|l|l|l|l|}
\hline Hebrew and & Meaning & Hebrew and & Meaning \\
\hline
\end{tabular}




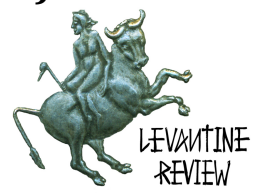

\begin{tabular}{|c|c|c|c|}
\hline Aramaic & & Aramaic & \\
\hline أَمُْسُا > زيّاح & Procession & محلر > إكليل & $\begin{array}{l}\text { Wedding, } \\
\text { nuptial rite }\end{array}$ \\
\hline همزمُمُلا > برشان & Sacred Bread & مهمحسال > إنشبين & Best Man \\
\hline سمُسمُ > نياحة & Eulogy & ومص:ل| > زكر انية & Remembrance \\
\hline עַצָרָרה> عنصرة & Pentecost & 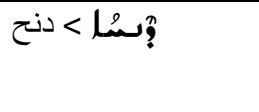 & $\begin{array}{l}\text { Baptism Feast, } \\
\text { Epiphany }\end{array}$ \\
\hline הוֹשׁשِעַנָא > شعانين & Palm Branches & حمدُم:! > عُمّاد & Baptism \\
\hline مَنَهمُا > أفقتوم & Entity & ص:2L/0/ > كِرازة & Homily \\
\hline ممدما > شمّاس & Deacon & 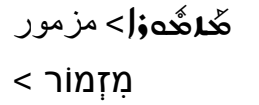 & Psalm \\
\hline
\end{tabular}

4. There are Hebrew and Aramaic elements, exclusive only to the written Christian Arabic. 25

\section{WORDS AND TERMS LINKED TO THE ARABIC BIBLE TRANSLATIONS}

By way of examining the Arabic translations of the Bible, we found an abundance of Hebrew-Aramaic words and terms pertaining to priestly laws, weights, measures, coins, animals, plants, and other related terms used in these translations. It seems that the translators found difficulty finding Arabic equivalents, and therefore resolved to keep the Aramaic and Hebrew originals. Nevertheless, there are Syriac

25 For more discussion see: Ibrahim Bassal, "Hebrew and Aramaic Words in Christian Arabic Bible Translations", pp.137-156, in- Festschrift Presented to Prof. Yizhak Avishur on the Occasion of his 65th Birthday, Ed. Michael Heltzer and Meir Malul, Archaeological Center Publications Tel Aviv 2004. [Hebrew] ; Ibrahim Bassal, "Hebrew and Aramaic Words in Christian Arabic Bible Translations", in Mituv Yosef - Yosef Tobi Jubilee vol. 1,(pp. 95-119), ed. Ayelet Oettinger and Danny Bar-Maoz, 3 vol. Bible, Medieval Literature, Modern Literature, The Centre for Study of Jewish Culture in Spain and Islamic Countries, University of Haifa 2011[Hebrew]. 


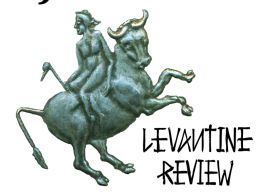

words linked to the translation of the Peshitta and the Christian liturgical literature. A sampling below is representative of our findings:

\begin{tabular}{|c|c|c|c|}
\hline $\begin{array}{l}\text { Hebrew and } \\
\text { Aramaic }\end{array}$ & Meaning & $\begin{array}{l}\text { Hebrew and } \\
\text { Aramaic }\end{array}$ & Meaning \\
\hline 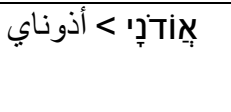 & My Lord & 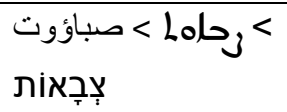 & Armies \\
\hline אֶלוֹהִים > ألو هيم & God & 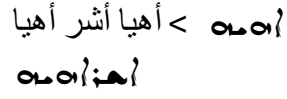 & I am that I am \\
\hline
\end{tabular}

Elements of the following words originate in the law of priests, and are characteristic to the Bible:

\begin{tabular}{|c|c|c|c|}
\hline $\begin{array}{l}\text { Hebrew and } \\
\text { Aramaic }\end{array}$ & Meaning & $\begin{array}{l}\text { Hebrew and } \\
\text { Aramaic }\end{array}$ & Meaning \\
\hline انأجِל > يوبيل & Jubilee & כְּרְרִּים > كروبيم & Cherubim \\
\hline שְׁרָפִים > سروفيم & Seraphim & לִ!!י'ים > لاويين & Levites \\
\hline עִצָצרָה > عنصرة & Pentecost & פפוּר > فפر & Purim \\
\hline 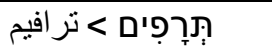 & Small gods & אַלְמֵגְגים > ألغو ميح & Corals \\
\hline جָּמוֹת > باموت & Altars & حمر > بيم & Stage \\
\hline 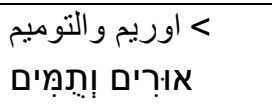 & Oracles & אֶרִיאֵל > أر ائيل & Altar Hearth \\
\hline אֵפוֹד > افود & Ephod & חַג יְהiֹֹה > حج الله & Feast of God \\
\hline 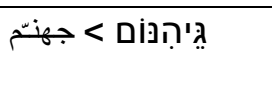 & Hell & 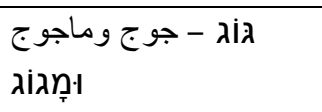 & $\begin{array}{l}\text { Gog \& } \\
\text { Magog }\end{array}$ \\
\hline 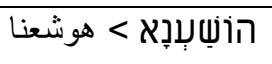 & Save Us & הֶחֶרים >> حرم & Destroy \\
\hline חַنְׁמַל > حشمل & Electricity & & Lizzard \\
\hline לִוְיְתָן > لاو يثان & Whale & نשְכִינָה > سكينة & $\begin{array}{l}\text { Divine } \\
\text { Dwelling }\end{array}$ \\
\hline > شيفور / سافور & Horn, Trumpet & אֵיפָה > إيفة & Ephah \\
\hline
\end{tabular}




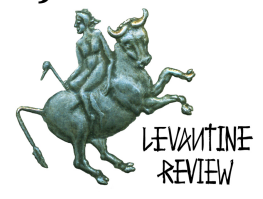

\begin{tabular}{|c|c|c|c|}
\hline م:090 & & & \\
\hline בַּת > باث & $\begin{array}{l}\text { A Liquid } \\
\text { Measure }\end{array}$ & חֹמֶר >حومر & $\begin{array}{l}\text { A dry } \\
\text { measure }\end{array}$ \\
\hline לֶתֶףך > لثוֹ & $\begin{array}{l}\text { A Barely- } \\
\text { Measure }\end{array}$ & לג > لج & $\begin{array}{l}\text { A Liquid } \\
\text { Measure }\end{array}$ \\
\hline קָב > قب & $\begin{array}{l}\text { A Measure of } \\
\text { Capacity }\end{array}$ & |مهـــ| > إستار & a coin \\
\hline حهز|/עוاרר > عور & chaff & & \\
\hline
\end{tabular}

Precious stones (breastplate stones) were likewise "Arabized" in relation to the Peshitta:

\begin{tabular}{|c|c|c|c|}
\hline Aramaic & Meaning & Aramaic & Meaning \\
\hline حزما > برقا & Topaz & ح:ل > >برولا & Onyx \\
\hline مaهa > يسب & Jasper & سمحيل > نقعثا & Jewel \\
\hline مهمها > سو مقا & Ruby & موملر > سفيلا & Sapphire \\
\hline قوب: > صديدا & Garnet & مسحسه > > قنكنون & Opal \\
\hline مزحبل > قرقدنا & Agate & حم حين عجل > & Amethyst \\
\hline مازمسم > تارسيس & Tarshish & ححمهLا > ككثوثا & Mole \\
\hline روزما > صفرية & Male Goat & لـهل> نون & Fish \\
\hline مهوسسا > شفنين & Pigeons & ممم:| > شمشار & Kind of Tree \\
\hline פ'زب > دار صيني & Cinnamon & إمص:حا > اشكر عا & Acacia \\
\hline עاרבים > عوربيم & Ravens & 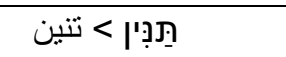 & Crocodile \\
\hline $\begin{array}{l}\text { حح:0ما يبروح/ييروحا } \\
\text { بيروح }\end{array}$ & Mandrakes & حهمعا > بهموت & Behemoth \\
\hline حهامسا > كوتين & Blouse & مريجه| > مصنفة & Headress \\
\hline
\end{tabular}




\begin{tabular}{|c|c|c|c|}
\hline ?ִפן > إندر & $\begin{array}{l}\text { Threshing } \\
\text { Floor }\end{array}$ & > فارش / بارش & Goad \\
\hline حزتـلما > برنشاء & Man & > > برشعثا & Son of an hour \\
\hline גָּלוּת > جالوت & Diaspora & هنحسا> جربي & North \\
\hline موملر > سفسل & Desk & סִפְּלָא > سفل & Cup \\
\hline פונדקיתא > فندقانية & Harlot & קهl >> جاو & $\begin{array}{l}\text { A Monastery, a } \\
\text { religious } \\
\text { community }\end{array}$ \\
\hline דִדַרש > درش & To practice & كif > طران & Cliff \\
\hline 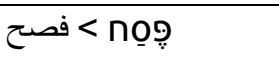 & Passover & حهزما > كرح & Monk's Niche \\
\hline صزן > كرز & Preach & ص:2010|> كاروزة & Homily \\
\hline مهمرئ| > مسطار & Wine & מִדְרָשש > مدر اش & School \\
\hline مرما > قصم & Necromancy & 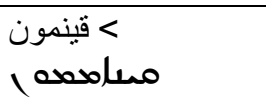 & Cinnamon \\
\hline زحا > راب & Rabbi & ;ححه| > ربيتا & Steward \\
\hline Lازمالر > ترمال & Rucksack & مهحيا > قلة & Basket \\
\hline معسا > قمين & Furnace & محملس > شبقتني & Left Me \\
\hline
\end{tabular}

Below is a sampling of the Aramaic words mentioned in the Arabic version of the New Testament (Gospels) and in Arabic liturgical Christian literature:

\begin{tabular}{|c|c|c|c|}
\hline Aramaic & Meaning & Aramaic & Meaning \\
\hline معهما > اقنوم & Entity/Person & مه حما > سُلاق & $\begin{array}{l}\text { Feast of } \\
\text { Ascension }\end{array}$ \\
\hline وسما > دنح & $\begin{array}{l}\text { Feast of } \\
\text { Emersion }\end{array}$ & 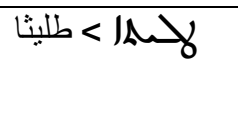 & Girl \\
\hline رحش| > طبيثا & Gazelle & محسا > سلبّح & Apostle \\
\hline
\end{tabular}




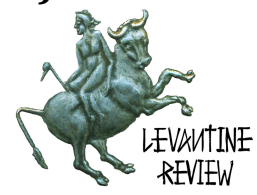

\begin{tabular}{|c|c|c|c|}
\hline هلمزا > فاتور & Table & مز:حسل| > مر عيث & Congregation \\
\hline مهملر > قوسال & Priest's Habit & ; ;ام > رازين & Last Supper \\
\hline معهم > قنوبين & Monastery & ? أمّام > اثقتح & Open \\
\hline ححه| > بيعة & Church & 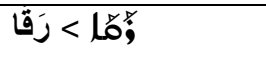 & fool \\
\hline 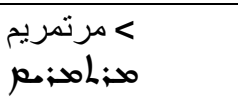 & Martha Mary & مخهبا > ملفان & Teacher \\
\hline
\end{tabular}

\section{REFLECTIONS ON THE HEBREW-ARAMAIC SUBSTRATA IN WRITING, PRONUNCIATION, FORMATION, SYNTAX AND VOCABULARY}

\section{Writing Matters}

Syriac-Aramaic words that end with a long vowel ta/-a are rendered into Arabic with a "linked T" (Ta Marbuta), an "expanded A" (Aleph Tawīla) or a "short A" (Aleph Maqsūra). For instance, طبيثا/طبيثة، صفريَّة/صفرى، صديدا، تخلثا

Furthermore, in handwritten documents in Christian Arabic, as well as other sources, there exists a body of words rendered into Arabic by way of the pattern that ends with "a". For instance:

\begin{tabular}{|c|c|c|c|}
\hline $\begin{array}{l}\text { Christian } \\
\text { Arabic }\end{array}$ & Meaning & $\begin{array}{l}\text { Christian } \\
\text { Arabic }\end{array}$ & Meaning \\
\hline إنشكر عا & Acacia & انقعثا & Diamond \\
\hline دنحا & $\begin{array}{l}\text { Emersion } \\
\text { Feast }\end{array}$ & بيروحا & Mandrakes \\
\hline سفيلا & Sapphire & صديدا & Turquoise \\
\hline طليثا & Girl & طبيثا & Gazelle \\
\hline
\end{tabular}

This pattern is characteristic of Syriac nouns, and it is likely to be a sign contributing to the identification of a Syriac noun-form.

Glottal consonants: א ה ח ע The performance of the glottal consonants "א ה ח ע ע" in borrowed words is similar to that in Arabic words - that is to say according to the phonemic regional performance in the dialect itself.

Begadkefat: Fricative and plosive $B$ is performed in two manners: $b / f$ 


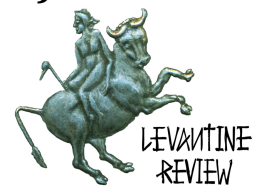

For example: Avishur أبيشور (Rome 1671 , 1 Chronicles 2: 16,) Avishai أبيشي (Paris 23 , 1 Samuel 21, 6,) Avigail أبيغايل (Rome 1671,1 Chronicles 2: 17,) Rahvia رحبيان (Rome1671, 1 Chronicles 23: 17,) Laban لابان (Rome 1671, Genesis 46: 25.)

The shift of Fricative $\underline{b}>f$ Rifka رفشقا الكاتب رفقا Rafshaki the writer (Rome version 1671, 2 Kings 18: 17) Avishur (Ms. Paris 23 ,1 Chronicles 28: 29).

The gimel is represented by $\dot{\varepsilon} / \underset{g}{g} / \breve{g}$ plosive and lax performances: plosive gimel: Gedeon جدعون (ms. Paris ,23 Judges 8: 30), Gershon جرشون (Rome,1 Chronicles 23: 7).

The lax performance: Peleg تفالغ (Ms. Sinai 2, Genesis 10:25), Togarnah توغرما (Ms. Sinai 2, Genesis 10:3); Eglon عغلون (Ms. Paris23 , Judges 3: 12), Goliath غولغ (external books, Dunlop 1901 page 45), Avigail أبيغايل (Rome 16711 Samuel 25:3).

$D$ is performed in two manners

A fricative performance:

أذرعي , Ms. Sinai 3 , Genesis 35: 28); يهوذا (Ms. Sinai 2, Genesis 28: 3) ذ: إيلثذي يبركك (Ms. Sinai 3, Deuteronomy 3) (اذوم" (Ms. Sinai 3, Genesis 36:8) and the same in the rest of places.

Plosive performance: أنا يلشدي ( Ms. Sinai 2, Genesis 17: 1), جدعون Gideon.

Lax $k$ is performed in two manners: $\dot{\tau} / s ; k / \underline{h}$ Zacharia إليملك (Rome1671) زكريا (Protestant edition), Elimelech زخريا (Maris 23,

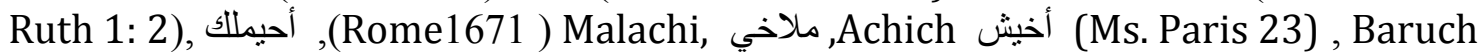
باروخ (Rome 1671).

Shift of $p>f / b$

For example: Orpha عرفا (Rome 1671, Ruth 1: 4 ), Peretz فارص (Rome 1671,Genesis 46:12)," "أوقع فور "and he made a lot" (Rome 1671, Esther 9: 24), فومي فوريم "Purim Days" (Esther 9: 26), Potiphar فوطيفر (Rome 1671, Genesis 46: 20), Paghur فاغور (Ms. Sinai 3 ,Deuteronomy 3: 26 ).

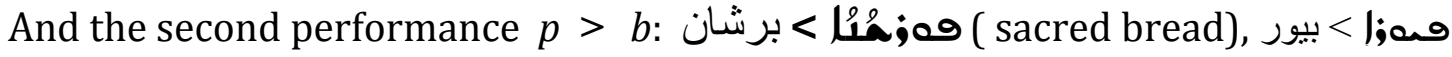
(nail).

Fricative $t$ is performed in the written Christian Arabic in $t$. hereinafter some examples that reflect the Syriac influence: "ايلث" (Ms. Sinai 3 , Deuteronomy 2: 8), كنرث (Ms. Sinai 3, Deuteronomy 3: 17), "لثامر كنثه" ( Ms. Sinai 3,

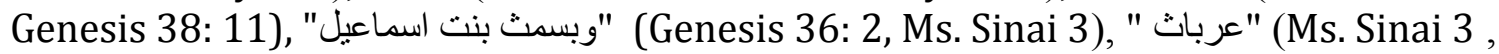

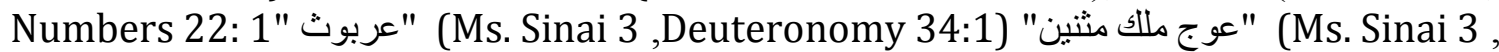
Deuteronomy 3: 1,3), يقال لها طبيثا/ طبيثةة (Ben Suleiman 1899, p. 112), بو اعيثة (Acts 9: 36, 


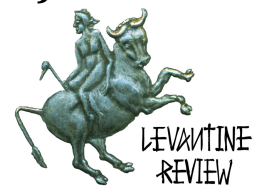

40), طليثا (Mark 5: 41), دوثن (Mpistle of James P. 50) (Mلصابوث (Ms. Sinai 2 Genesis 33: 17), "وجاث" "واثا (Ms. Sinai 3 , Genesis 35: 19), دونا (Ms. Sinai 3 Joshua11: 23).

Shift of ${ }^{\varsigma}>\dot{g}$

Fence tower ( Ms. Sinai 3, Genesis 35:21) رغويل Reuel ( Ms. Sinai 2, Genesis

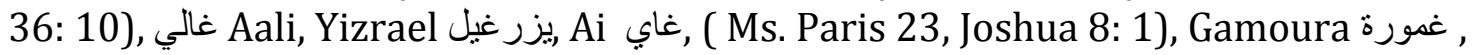

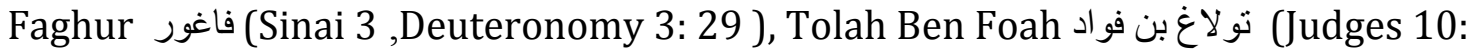

1,), Gomri غمري (Ms. Paris 23, 1 kings 16: 6).

shift of $\underline{h}>\underline{h}$

The shift of $\underline{h}>\underline{h}$ is prominent in nouns, for example: اخيملك Achimeleck (Ms. paris 23,1 Samuel 21: 2), أخيطوب Achituv (Ms. Sinai 23, 1 Samuel 22: 9), خامطا Lazard (Rome 1671, Leviticus 11: 29-30), pottery mountain ارض خر اس (Ms. Paris 23, Judges 1: 35), ( Nahash ناخاس Ms. Paris 23, 1 Samuel 11:1).

The shift of $\check{s}>S$

For example: سمجر Shamgar ( Ms. Paris 23, Judges 3: 31), كو سان Koshan (Ms. Paris 23, Judges 3: 8), كاموس Kamush ( Ms. Paris 23, Judges 11: 24), اخيس Achich (Ms. Paris 23, 1 Samuel 21: 11), سمعون Shimon (Ms. Paris 23, Jushua 19: 1), منسا Menasheh (Ms. Paris 23, Joshua 17: 2).

\section{MORPHOLOGY}

The verb

Forms in the "pa'al" (3, past, singular) on the Aramaic manner: سماع (haw), فْشاع (saw).

The media $W$ verbs conjugate as media $Y$ verbs: 'anayyim (make sleep), 'a'ayyim (awake).

The form (or pattern) fau'ala $>\boldsymbol{f o ́}^{\boldsymbol{c}} \boldsymbol{a l}$ monophtongization: (bōrad) became cold, (nōzal) catch cold, (föfaš) weakened.

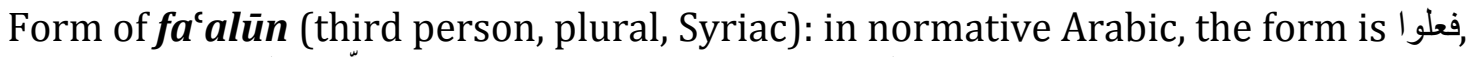
for example: صلّون عليه (prayed for him), ودعون لبلاد كسروان (asked for Kisrawan country), وملكون (they gave), ومطون (they ruled).

The form šaf'ala

Examples from spoken Arabic: شلهب (reddened), شقلب (turned over) ششقل (weighed). 


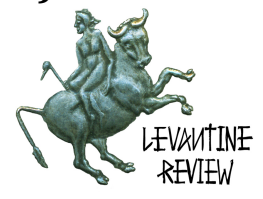

The starting letters of the future tense are expressed in the vowels like Aramaic: [i] yiktib (write) yismac (hear).

New verb forms, part of them, denominative verb:

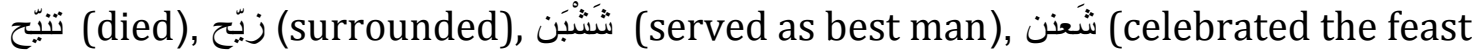
of palm branches شبقتح (forsaken me), شمّسن (serve as a deacon), عنصن (celebrated Pentecost), تشرن (Autumn arrived), قصدم (used magic), كنّ (performed the wedding), حرن (destroy).

The Noun

Aramaic name patterns used in Arabic:

fa'alüt pattern

These nouns terminate with suffix-ūt, the form indicates abstract nouns:

ناسوت (humanness), ملكوت (kingdom), بهوت (animals), كهوت (priesthood).

fā'cūl pattern

قاتول (murderer), شافور / صافور (horn), شاصوم (knew), شاقول (weight tool شورب (garden fork), جاروشة (grinder), حالول (sieve).

fǘīl pattern

This pattern is not mentioned among those brought by Sibawaihi: this pattern exists in Aramaic and in Syriac as a form of "Kūtinnā", and doesn't exist in Arabic. It exists in the Bible translations in the Christian Arabic, for example: كوتين (blouse).

Supplanting in the patterns $\boldsymbol{f i}^{\mathrm{c} \boldsymbol{\mathbf { i }} \mathbf{l}}>\boldsymbol{f a} \boldsymbol{a}^{\text {'c } \boldsymbol{i} \mathbf{l}}$

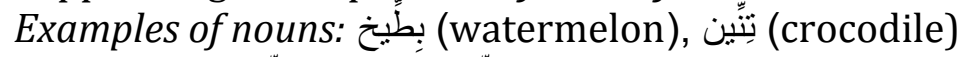

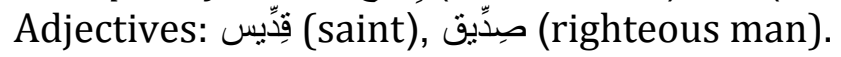

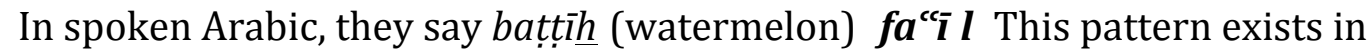
Aramaic and Syriac.

Fay'ül pattern فيعول exists in Arabic, though rare. The form شيفور (horn) is borrowed from the Syriac, سيعور (scapegoat).

Adaptation according to the Arabic pattern: the word ephod is performed in Arabic

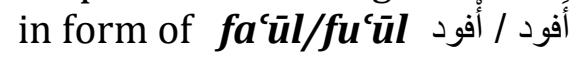

The Syriac plural form in the emphatic state (-aiyā) used in Arabic:

وملكوا كل مارونيا / وكتبوا القرايا (Maronites rules, and wrote to villagers).

The Hebrew plural forms -im:

Hebrew names serve with thus form, for example: بعليم (owners), عوربيم (crows), الموجيم (corals). 


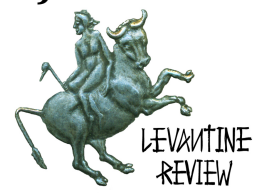

The shift kum > kon أخوكن (your brother), اضضربهن (I will hit them).

The nisba form āni , for example: براني (external), جواني (internal), الفوقاني (Ms. Sinai 3, Daniel 9: 2).

The Syriac form of diminution: ōn/ūn $\overline{\boldsymbol{u}} \boldsymbol{s} / \overline{\boldsymbol{o}} \boldsymbol{s}:$

For example: طلموسة (piece of bread), جملون (wooden seat like hump of camel), كر عونة (small leg).

The production of blended or compound forms توبدانيات > بمح which is one of the church terms. It returns in anaphoric form in the heads of prayers "tov deen". بـ (take what belongs to you and give me what belongs to me). The form is a Syriac word composed of the words 'bar' and 'shaata'. The word is a Syriac word composed of the words 'bar' and 'nasha'.

Addition Prosthetic Aleph

Adding Prosthetic Aleph (at start) in order to prevent the beginning of a word with a number of consonants, for example: إنبين (best man), إصحاح (chapter), إكليل

(wedding), إزميل (chisel). This phenomenon even exists in Hebrew in words such as אצטדיון (stadium).

\section{SYNTAX}

"la" as an object marker 26

For example:

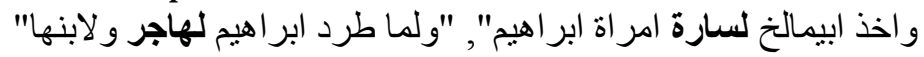

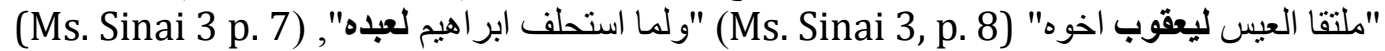
"و امر الهه (Ms. Sinai 3, p. 12) "ولما قتل موسى للمصري ودفنه في الرمل" (Ms. Sinai 3, p. 10)

(Ms. Sinai 3, p. 13) لبه الني اسر ائيل" (Ms. Sinai 3, p. 14)

Concord

Suitability gender and number between subject and verb, for example:

"قالوا الروم للامبر اطور / هذا هو الملك المنصور", "بكوا النصارى على الاخوة / وقالوا يا حيف بلاد لله نخوة".

These verbs in normative Arabic are likely to be in singular.

26 For more discussion see: Arieh Levin, "The Particle "LA" as an Object Marker in Some Dialects of the Galilee", Zeitschrift Für Arabische Linguistik 16 (1987), pp. 31 - 40; Simon Hopkins, "on the construction šmēh l-gabrā 'the name of the man' in Aramaic", JSS 42 (1997)pp. 23-32. 


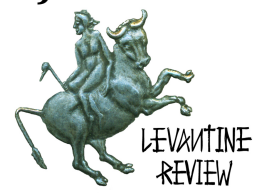

The inner object precedes the verb:

I will increase your descendants_(Genesis 16:10), ملكه تمثلك do you intend to reign over us? (Genesis 37: 8), موتا نموت we are doomed to die (Judges 13:22).

In Arabic the verb precedes the name.

\section{VOCABULARY AND SEMANTICS}

A great part of the borrowed elements are nouns. In addition, adjectives and verbs are also borrowed, but in an inflection of Arabic. This grammatical division in percentages shows that the percentage of nouns among those that I discussed is $82,7 \%$, adjectives $2.1 \%$, verbs $14 \%$, adverbs $1.3 \%$.

There are clear guidelines that indicate the absorption of these words in Arabic:

(1) The Arabic definite article mark: in other words, adding 'Al' to borrowed words: for example:

الفصح (Passover), العنصرة (Day of Pentecost), اليوبيل (Jubilee), الجربي (north), ألأر اييل (alter), الساروفيم (seraphim), الدنح (feast of emersion.)

(2) The adaptation of the Arabic plural manner: (The Arabic broken plural) محازير (cycles), مداريش (schools), تشارين (Tishri month), حو اكير (ground), اججاجين (jars), سوافير (horns), شعانين (feast of palm branches), ألأجاجير (roofs).

(3) Preserving the Hebrew plural form: In the written Christian Arabic, certain nouns continue to perform the Hebrew plural way: عوربيم (gems), كوريم (ravens), باموت (alters), كروبيم (cherubim), اورريم وألتوميم (porches) (oracle).

(4) Borrowing foreign words, the basic form and the additional suffix, e.g, diminution suffix: ōn/ūn ūs/ōs: علموسة (piece of bread), عمروس (young lamb, جملون sloping pattern).

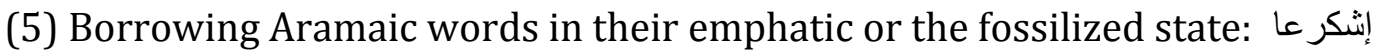
(acacia) سيروحا (mandrake), سفيلا (sapphire), طليثا (garnet), طبيثا (gazl) سومقا (sumac), تخلثا (azure).

(6) Combinations that were produced through blend or compound manner: درنساء برنشاء (man), توبدانيات (again and again), بيلاتي / ديلاتك (yours), بيدر ( (threshing floor)

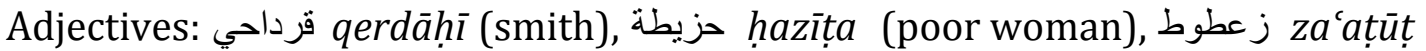
(tiny). 


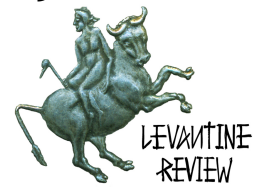

Verbs in Arabic forms: شمّس (served as a deacon), زيّح (went around the church), تشرن (October has begun).

\section{Semantics}

In the oral and written Christian Arabic, there are words that are lexically borrowed directly into Arabic, through phonemic and morphemic changes and sometimes the form remains as it occured in the borrowed language. For example: إنكر عا (acacia), نخلثا (azure), حشمل (mandrakes), طليثا (girl), طبينا (electricity)

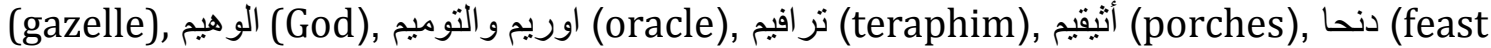

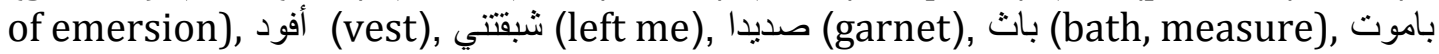
(altars), كونثونا (mole), كونين (blouse).

Another technique of semantic copying is a partial or full phonological and morphological adaptation of the borrowed word into the borrowing language, and the use of the definit article and the grammatical inflection of the borrowing language, for example in the written Christian Arabic:

الأندر (threshing floor), أسكوليين (scholars), بيعة (church), جالوت (Diaspora), جربي

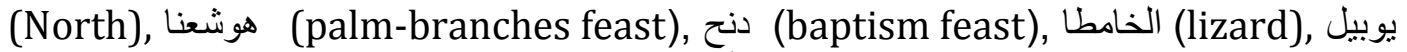

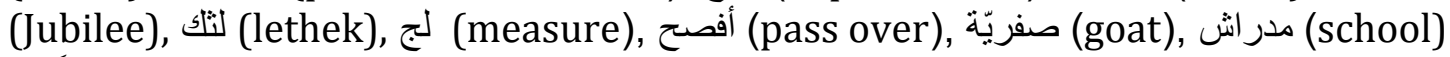
قَصَحَ (involved in magic), قصم (divine), قاصوم (future teller).

A semantic borrowing (loan translation - calque)

In spoken Christian Arabic: fini (I can), Isān 'ittōr (tongue of ox), Isān 'il'asfür (bird's tongue, plant), klīl 'ijjabal (cercis, plant), 'așā 'irrā'y (goose grass, plant).

Examples from the written Christian Arabic:

Burn offering- صعيدة, tabernacle قبة الزمان/ خبا الزمان, evening offering- قربان المسا/العشي, ace

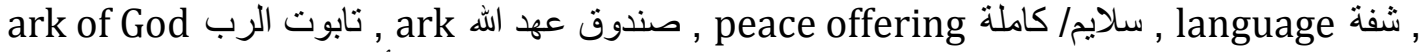
dawn gazelle أيلة الصبح , عين عجل- eye of calf, feast of God حج الته

Semantic expansion

In a number of words, there is a semantic expansion of meaning in the borrowing language: In the spoken Christian Arabic, we mean by 'ittoray (Pentateuch), the whole Bible. Here the meaning was expanded by metonymic shift (the part expresses the meaning of the whole).

The main meaning of the word كليل is crown. In Christian Arabic, there took place a semantic expansion of the word and it is used to connote a wedding ceremony اكليل. Likewise he word "Satan" is used in the spoken Christian Arabic to connote a troublesome kid. It should be noted that in the language of Jewish wisemen, Satan firstborn (Yibamot 3: 1), but other words are derived from this noun, تشيطن "did troubles and deeds of Satan." 


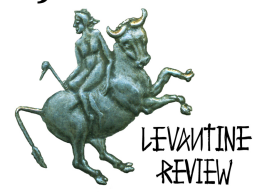

An example of a semantic narrowing: the word اصحاح from the Syriac رمسا which means a book or a copy or a chapter in a book. In both spoken and written Christian Arabic, it means a chapter in the Bible or the New Testament.

The Arabic vocabulary spoken and written by Christians is exclusive. The exclusiveness stems from the religious and social linkage of Christians to Holy books and to Syriac and Aramaic sources and also to Hebrew and Jewish-Aramaic. Besides, The majority of the Christian residents of the area under investigation spoke SyriacAramaic in times past, therefore its normal to have some residues from those languages, thus preserving the linkage to the Aramaic, Syriac and Hebrew sources.

In the course of examining this vocabulary, I discovered its exclusiveness, reflected in terms and combinations, exclusive to Christian communities, in the spoken Arabic in which, the words in many cases are common to other groups. Also in the written Christian Arabic, exclusiveness in words and terms is prominent, and identical terms do not exist in the general Arabic of Moslems.

I have detected tens of Hebrew and Syriac-Aramaic words, used in written Christian Arabic, which are not mentioned in classical Arabic dictionaries, even in late ones. I tried, as possible as I could, to complete that vocabulary and to show its exclusiveness. Below are the Hebrew and Aramaic words that are not included in the classical Arabic dictionaries, and which are found in Christian Arabic writings:

باث (bath, measure), حاموت (altars), حومر (homer), حرو (electricity), حرّم (destroy),

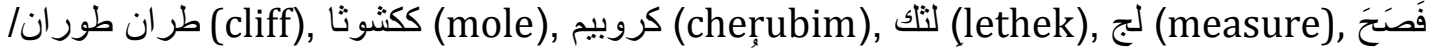

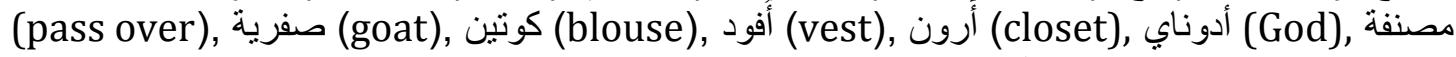

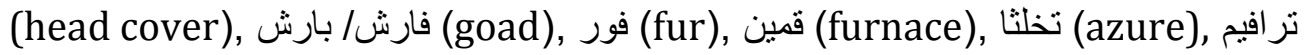

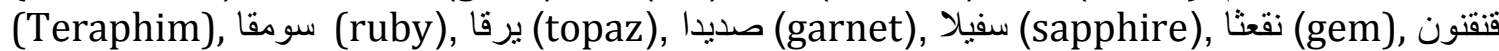
(opal), قرقدنا (agate), سفسل (desk), أوريم و التوميد (oracle), هين (porches (

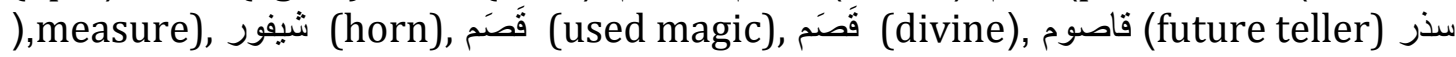

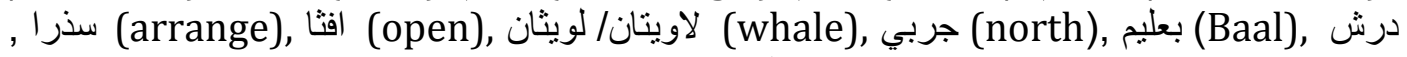

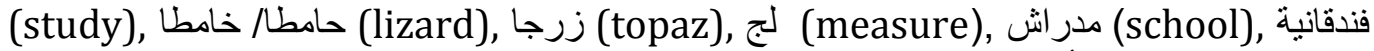

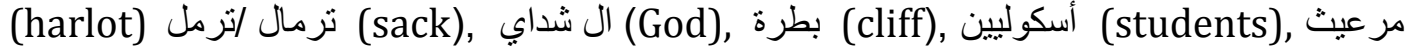
(congregation), أشنكر عال ترل (acacia).

\section{HEBREW AND ARAMAIC WORDS THAT ARE NOT INCLUDED IN AL- BARGHOUTI'S DICTIONARY OF THE PALESTINIAN ARABIC DIALECT}

In the spoken Christian Arabic, there are many words that were not included in the Barghouthi dictionary about the Palestinian Arabic dialect. I have pointed at this lacuna in the introduction of my doctoral dissertaion. ${ }^{27}$ These words exist and are

27 Bassal 2004. 


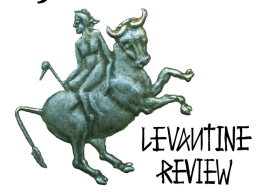

common among the Arab-defined Christians in the North of Israel. Hereinafter, more than fifty such words, omitted in the Barghouthi dictionary, are still in use by Christians in the North. They are as follows:

أفّور (small basket), برشان (sacred bread), بيور (wooden nail), دلّيل (thin), دفورة (first

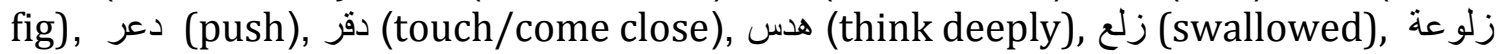

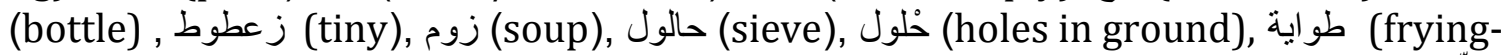

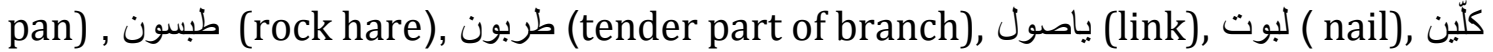

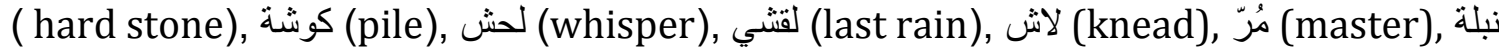
( fallen fig), نير (yoke), سفار (wooden logs), سطريدة (basket), عابورة , سطرة (clap) (passing), عافوق (parasite plant), عبيط (idiot), فاكورة (confined), فاروة (chaff), فجروة (crit) (damage), صر افة (wooden box), قطريب (cross piece of yoke), قرداحي (smith), قبرحة (che (beams), شبرحي (talk freely), شورة (1ine), شَلَف (stole), شعريّة (gate), شرتح ( شرنقة (cocoon), شلوط (burn), شبشول (corn hairs).

Words mentioned in the New Testament and in the liturgical Arabic Christian

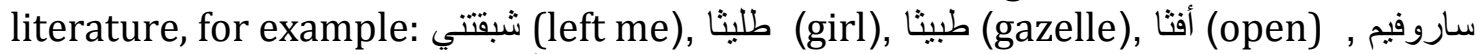
(seraphim), رقا (idiot), أسكوليين (students), بر عيث (congregation), بثيث (virgin) , سياميذ (putting hands).

As known, the religious-social exclusiveness of the Arab-defined Christians and their linkage mostly to their Aramaic roots, is reflected in the domain of their language, both spoken and written. The vocabulary of the Arab-defined Christian community in Israel as a whole is the same as that of the Arab Moslems. However, the speech of the Arab-defined Christians is exclusive to their religious specificity and their geographical and cultural links to the region of Syria and Lebanon in the near past, in addition to their orientation to the West. This is expressed in the private names, characteristic to Christians: Putros, Hanna, Geries, Michael, Samuel, George, Charles, Anton, Cherbil, Barbara. These names are common among the Christian community and reflect a belonging to that community. Also in the names of educational and cultural institutions, we notice the use of exclusive names to the Christian community: Terra Santa, Mar Yosef, Mar Ilias, Maryam Bawardi, Mar Geries, Cleric School. Moreover, there are words and terms linked to church and the church's surroundings and religious ceremonies. Among them are the following:

هيكل (temple), دير (monastery), خوري (priest), شماس (deacon), أسقف (bishop), مطران (arch-bishop), بطرك (patriarch).

Words linked to feasts and religious life rituals include: إكليل (crown), إنبيل (best

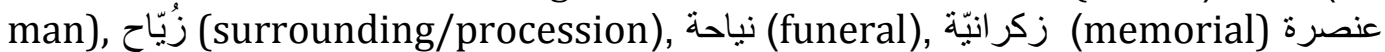

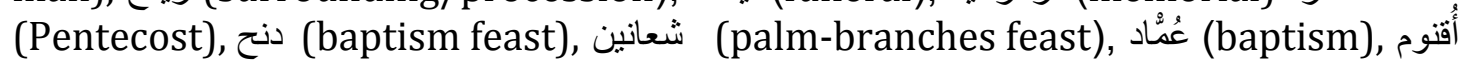

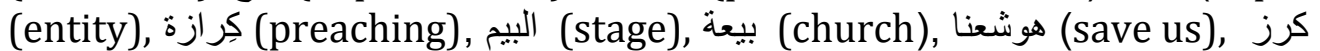
(preach), سفان (guide/teacher), سفسل (desk), سلاّح (ascension feast), هرق (apostle), 


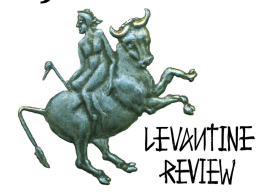

قلاية (monk's house), رازية (monastery) ربين (last supper), ربيبين (house-wife), رقازينا (stupid), شبقتني (left me), نشفلة (basket), ترمال (rucksack).

\section{CONCLUSION}

In summary, I can say that the spoken and written Christian Arabic is a linguistic register within the Arabic language. One may say that it is Arabic, but an Arabic that has exclusiveness that distinguishes it from the common Arabic language. It is a distinct language form that is bound to ethnic-religious, cultural, social and geographical variables. The affinity that Christians feel to Christian literature, whose origin is in the Syriac and Greek languages, and which abounds in Greek and Syriac influences, cannot be overstated. The geographical closeness of Arabic-speaking Israeli Christians to Syria and Lebanon made the Syriac and Aramaic influence so outstanding in their spoken Arabic, and their historical and cultural linkage to Syrian and Lebanese Christians is prominent in their lifestyles, their customs, and even their spoken and written languages.

* Ibrahim Bassal is Head of the Hebrew Department at the Academic Arabic College of Haifa. His main areas of research and writing are in Comparative Semitic Linguistics and the study of Christian Arabic translations of the Syriac Bible. His forthcoming book on the latter topic is An Early Copy of the Arabic Pentateuch (MS Sinai Arabic 2): Study, Text, and Notes. 


\section{Bassal / The Levantine Review Volume 4 Number 1 (Spring 2015)}

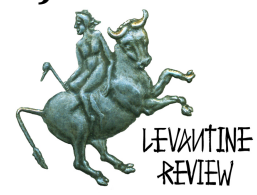

\section{Bibliography}

Abba Ben-David, Biblical Hebrew and Mishnaic Hebrew, Dvir, Tel-Aviv 1967, vol. I, pp. 153-65.

Abed Khariush, Palestinian Dialects- A Phonological Study, Amman 2004.

Adam Carter McCollum, "Garshuni as it is: Some Observations from Reading East and West Syriac Manuscripts", Hugoye: Journal of Syriac Studies, Vol. 17.2 (2014), 215-235.

Aghnatius Ya'qūb III, al-Barāhīn al-Hissiyya 'ala Taqāruḍ al-suryāniyya wa'arabiyya, Damascus 1969.

Aharon Maman, “On identifying Hebrew Elements in Judeo-Maghrebian”, Masorot 3-4 (1989) pp.171-201 [in Hebrew]

Ahron Geva-Kleinberger, Autochthonous texts in the Arabic dialect of the Jews of Tiberias, Wiesbaden: Harrassowitz 2009.

Ahron Geva-Kleinberger, Die arabischen Stadtdialekte von Haifa in der ersten Halfte des 20, Wiesbaden: Harrassowitz 2004.

al- Ğawālīqī, al-Mu ${ }^{\varsigma} a r r a b$ min al-Kalām al-ª $a^{\varsigma}$ ğamī, ed. F. ' abd Al-Rahịm, Damascus, 1990.

Arieh Levin, A Grammar of the Arabic Dialect of Jerusalem, Magness Press, Hebrew University, Jerusalem 1995.

Arieh Levin, "The Particle "LA" as an Object Marker in Some Dialects of the Galilee”, Zeitschrift Für Arabische Linguistik 16 (1987), pp. 31 - 40.

Gotthelf Bergstrasser, Sprachatlas von Syrien und Palastina, Leipzig: J.C. Hinrichs 


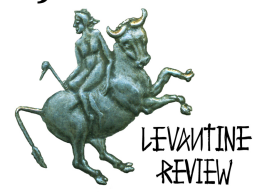

1915.

Haim Blanc, Studies in North Palestinian Arabic. Linguistic Inquiries among the Druzes of Western Galilee and Mt. Carmel, Jerusalem 1953.

Haim Blanc, The Arabic Dialect of the Negev Bedouins, The Israel Academy of Sciences and Humanities, Jerusalem 1970.

Heiniki Palva, Lower Galilean Arabic: An Analysis of its Anaptyctic and Prothetic Vowels with Sample Texts, Helsinki 1965

Ibrahim Bassal, "Hebrew and Aramaic Words in Christian Arabic Bible Translations", in- Festschrift Presented to Prof. Yizhak Avishur on the Occasion of his 65 th Birthday, (pp.137-156), Ed. Michael Heltzer and Meir Malul, , Archaeological Center Publications Tel Aviv 2004. [Hebrew]

Ibrahim Bassal, "Hebrew and Aramaic Words in Christian Arabic Bible Translations", in Mituv Yosef - Yosef Tobi Jubilee vol. 1,(pp. 95-119), ed. Ayelet Oettinger and Danny Bar-Maoz, 3 vol. Bible, Medieval Literature, Modern Literature, The Centre for Study of Jewish Culture in Spain and Islamic Countries, University of Haifa 2011. [Hebrew]

Ibrahim Bassal, "Syriac-Aramaic words in an early Christian Arabic copy of the Pentateuch (Ms Sin. Ar. 2), Collectanea Christiana Orientalia (CCO) 10 (2013), pp. 17-36.

Ibrahim Bassal, Hebrew and Aramaic elements in the Vernacular Christian Arabic in Israel and in the written Christian Arabic in the Holy Land, Syria and Lebanon, (Dissertation), Haifa University, 2004. [in Hebrew]

Joseph Hobeika, Etymologie arabo-syriaque. Mots et Locutions Syriaques dans l'Idiom Vulgaire du Liban et de la Syrie = al- dawātir. baht fì baqāyā al-luġa alsuryāniyya fì al-lug̉a al- 'āmmiyya fï Lubnān wa-sūriyya 2 vols. (Jounieh 19023/Byrouth-Basconta.

Joseph Naveh \& Jonas C. Greenfield, "Hebrew and Aramaic in the Persian Period" in The Cambridge History of Judaism, pp. 115-129 (ed.), W.D. Davies, L. Finkelstein, Cambridge vol. I, 1999. Judith Rosenhouse, The Bedouin Arabic Dialects, General Problems and a Close Analysis of North Israel Bedouin Dialects, Wiesbaden 1984.

Kees Versteegh, Pidginization and Creolization: The Case of Arabic, Amesterdam/Philadelphia: John Benjamins Publishing Company 1984.

Kees Versteegh, The Arabic Language, Edinburgh University Press 2014. 


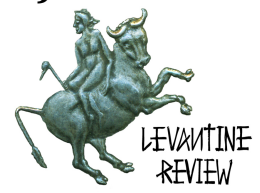

Louis CHeikho, Le Christianisme et La Littérature Chrétienne en Arabie Avant L'Islam, 2 édition, Dar-El-Machreq, Beyrouth 1989.

Michel Feghali, Étude sur Les Emprunts Syriaques dans Les Parlers Arabes du Liban, Paris 1918.

Michel Feghali, Le Parler de Kfar 'Abida (liban-syrie) -Essai Linguistique sur La Phonétique et La Morphologie d'un Parler Moderne, Paris 1919.

Michel Feghali, Syntaxe des Parllers Arabes Actuels du Liban, Paris 1928.

Mosa Shawarbah, On the Bedouin Dialect of the Tiyaha in the Negev: Phonology, Morphology, and Selected Syntactical Issues (Dissertation) 2007 [Hebrew]

Moshe Bar-Asher, "Eléments hébreux dans le Judéo-arabe marocain, LEŠONENU 42 (1978) pp. 163-189. [in Hebrew]

Moshe Piamenta, The Use of Tenses, Aspects and Moods in the Arabic Dialect of Jerusalem. Jerusalem, Bureau of Adviser on Arab Affairs, Prime Minister Office 1964.

Ora Schwarzwald, "Determining Criteria for the Fusion of the Hebrew-Aramaic Component in Judeo-Spanish. Milet 2 (1984), (Everyman's University Annual), 357-367. [in Hebrew]

Otto Jastrow, "The Arabic Dialects of the Muthallath (central Israel)" JSAI 29 (2004), pp. 166-175.

Rony Henkin, Negev Arabic: Dialectal, Sociolinguistic, and Stylistic

Variation. Wiesbaden: Harrassowitz 2010.

Rufa'el Naxleh al-Yasū`y, GHarā’ib al-Lugha al-'Arabiyya, al-Mațba'a alKāthulikiyya, Beirut 1959.

Salomon Dov Goitein, "The Hebrew elements in the vernacular of the Yemenite Jews", LEŠONENU 3 (1931), pp. 356-380. [in Hebrew]

Sigmund Fraenkel, Die Aramäischen Fremdwörter im Arabischen, Leiden 1886.

Simon Hopkins, "on the construction šmēh l-ḡabrā 'the name of the man' in Aramaic", JSS 42 (1997)pp. 23-32.

Spencer Trimingham, Christianity among the Arabs in Pre-Islamic Times, London 1979.

Stephen Kaufman, The Akkadian Influences on Aramaic, Chicago 1974. Wolf Leslau, "Hebrew Elements in the Judaeo-Arabic Dialect of Fez" J.Q.R. 36 


\section{Bassal / The Levantine Review Volume 4 Number 1 (Spring 2015)}

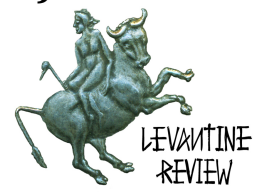

(1945), pp. 61- 78.

Yaakov Bahat, La Composante Hébraïque de l'arabe écri des Juifs du Maroc, Institut Bialik, Jerusalem 2002.

Yehoshua Blau, "Etymologische Untersuchungen auf Grund des palästinischen Arabisch", Vetus Testamentum 5 (1955), pp. 337-344.

Yehudit Henshke, Hebrew Elements in Daily Speech: A Grammatical Study and. Lexicon of the Hebrew Component of Tunisian Judeo-Arabic, Jerusalem, 2007. [in Hebrew]

Kutscher, Hebrew Encyclopedia, 1971 vol. 5, p.968. Yihizkiel

Yitzhak Avishur, "The Ancient Aramaic Elements in the Iraqi Judaeo-Arabic", Masorot 9-10-11, (1997 Jerusalem), pp. 277-94. [in Hebrew] 